\title{
ACTITUDS AL VOLTANT DE LA COEDUCACIÓ
}

\author{
Elena Posa
}

L'existència de l'escola mixta o coeducativa encara no s'ha normalitzat al nostre país. Les primeres defenses de la mixtitat sorgeixen en el marc del pensament tacionalista $i$ igualitari. La igualtat de tots els individus ha de comportar també la paritat entre homes i dones en l'educació. I una integració de les dones a l'escola masculina ha de servir per a formar millor la dona, sense que això vulgui dir qüestionar els rols que tradicionalment se li assignen. D'alguna manera l'escola mixta també ha continuat essent una escola sexista que ha intentat fer-se extensiva de la comunitat entre homes i dones que es troba a la societat i a la família.

El franquisme ha fomentat l'opressió de la dona i la separació dels sexes també a l'escola. Assumia obertament que les funcions d'homes $i$ dones eren totalment diverses $i$ que calia educar les nenes prioritàriament per a la seva missió en la família. La separació ha accentuat la inferioritat. El debat sobre la coeducació s'ha d'orientar partint de la falsa aparença igualitària i del caràcter essencialment masculí dels valors que la componen. 
L'escola mixta encara no és legal al nostre país, però especialment a partir de l'aplicació de la Llei d'Educació s'ha estès considerablement, sobretot a l'ensenyança privada.

El problema de la discriminació educativa de les nenes i les dones queda resolt amb la coeducació? No ho pensen així moltes ensenyants que han constatat com també l'escola mixta és una escola sexista que o bé oblida la situació d'opressió en què les nenes i les dones es troben en la societat, creient que tot queda resolt amb la igualtat formal, o bé fomenta obertament actituds $i$ activitats diverses en els nens $i$ les nenes que configuraran llurs respectius rols sexuals i socials. La cultura i els valors que assumeix l'escola mixta són aquells que tradicionalment han creat i interioritzat els homes. A les nenes com a màxim se'ls proposa accedir a aquesta cultura masculina, mentre que la família i tots els mitjans de socialització fomenten en elles tot el ventall d'actituds, valors, virtuts i coneixements que són considerats femenins. La desigualtat de partida augmenta i es fa més palesa a mesura que la nena creix. ¿Ha de ser nena en una escola pensada per als nens? ¿O ha d'intentar defugir el model social que se li proposa per intentar ser $\mathrm{i}$ fer com els seus companys? En un $\mathrm{i}$ altre cas serà menys acceptada que els nens, perquè tot el femení és menys valorat i perquè tampoc no es permet que les dones transgredeixin la norma social. Cal plantejar-se, doncs, una escola que no sigui només mixta físicament sinó també en els seus valors, en la seva cultura i en els seus continguts:

Fer una ullada a les posicions més rellevants sobre la coeducació al nostre país i a la política aferrissadament separatista que ha mantingut el franquisme pot contribuir al debat sobre una escola en què també les nenes hi tinguin el seu lloc i el seu dret.

\section{Les primeres defenses de la coeducacio}

El debat sobre la coeducació s'inicia el segle passat, quan la concepció de l'educació com un element essencial per al progrés social comença a 
estendre's tant entre la burgesia com entre els treballadors i quan comença a desvetllar-se al nostre país un incipient feminisme.

Durant el segle xIx també comença a plantejar-se la necessitat que les dones rebin algun tipus d'educació escolar. S'està consolidant el model de família burgesa que coneixem actualment i l'educació de la dona es veu com una contribució important a la salut moral de la llar i dels infants.

Els sectors més avançats de la burgesia intenten sostreure l'aparell escolar de las mans i de la influència de l'Església, i proposaran una escola humanista, racionalista, igualitària i laica.

És en aquest marc que l'escola comença a orientar-se com un dret de tots els individus - i per tant també de les dones-, i com un mitjà per a combatre l'endarreriment cultural i social. Es considera que les dones podran complir llur missió a la vida de forma adequada si han estat convenientment educades.

Les feministes de l'època defensaran vivament el dret de les dones a una educació com la que reben els homes i en aquesta òptica Emilia Pardo Bazán proposa en el Congrés Pedagògic del 1892 la coeducació a tots els nivells per tal de superar la divisió de funcions entre l'home i la dona. En aquells moments la proposta és en part ben acollida, però no preval en les votacions finals.

L'Escola Moderna de Ferrer i Guàrdia i, ja abans, la Institució Lliure d'Enseyança van ser peoneres en la defensa i en la implantació de la coeducació. Ferrer i Guàrdia acceptava plenament la divisió tradicional de funcions entre home i dona, i propugnava la coeducació com l'únic mitjà per a fer de la dona la vertadera companya de l'home. ${ }^{1}$

Per la seva banda, la Institució Lliure d'Ensenyança exposava en els seus principis pedagògics que «la coeducación es un principio esencial del régimen escolar y que no bay fundamento para probibir en la escuela la comunidad en que uno $y$ otro sexo viven en la familia $y$ en la sociedad. Juzga la coeducación como uno de los resortes fundamentales para la formación del carácter moral, así como la pureza de costumbres, y el más poderoso para acabar con la actual inferioridad positiva de la mujer, que no empezará a desaparecer basta que aquélla se eduque, en cuanto a la cultura general, no sólo como sino con el hombre».

1. Geraldine Scanlon, La polémica feminista en la España contemporánea, Siglo XXI, Madrid, 1976, pp. 51-52.

2. Pedro Cuesta, Ideario pedagógico, dins «Cuadernos de Pedagogía», núm. 22, 1976. Vegeu també Giuliana di Febo, Orígenes del debate feminista en España, dins «Sistema», núm. 12, Madrid, 1976. 
En aquesta declaració es reconeix la situació d'inferioritat de la dona, però s'atribueix als costums, a l'educació, sense replantejar-se les funcions que com a dona li són assignades, particularment a la família. Al contrari, l'escola ha de fer-se extensiva de la comunitat familiar i social en allò que es refereix als sexes, sense qüestionar el caràcter d'aquesta comunitat. A més la coeducació propugnada és la millor manera per a neutralitzar la sexualitat, garantint «la formació del caràcter moral i la puresa de costums». L'emancipació de la dona era vista com la seva integració en el món masculí, en aquest cas el de la cultura dominant, sense discutirne ni valorar-ne els continguts, que són els qui menystenen tot allò que es considera femení. ¿Com havien de ser educades unes nenes les quals com a futures dones es considerava corn a peça clau de la família, i enlloc més, $i$ les quals simultàniament calia instruir, encara que només fos en els primers nivells, en les idees i els coneixements d'un món que ni pel passat ni pel futur previsible podien considerar com a propi?

Però totes les diferències s'amagaven sota un plantejament paritari que coincidia amb el del moviment feminista de l'època: reivindicar l'accés de les dones a les professions reservades als homes, el dret a vot o a l'educació.

La divisió de rols, i per tant la necessitat de preparar-se, també a l'escola, per a les tasques respectives que corresponen a cada sexe - la llar per a la dona-, queda insinuada quan es diu que la dona s'ha d'educar com l'home «en cuanto a la cultura general». La porta de la cultura particular femenina que havien de rebre les nenes continuava oberta $i$ no tant per a poder donar des de l'escola totes les habilitats i tots els coneixements necessaris per a tenir cura d'una família com per a recordar dins del marc de la cultura general, que rebien conjuntament, que les nenes tenien la seva pròpia «cultura» i les seves prioritats a la vida.

De totes maneres, hem de veure aquestes posicions com a avançades en l'època en què es produïen: extraordinàriament avançades si considerem el marc hostil en què naixien i la pràctica inexistència d'un moviment feminista que plantegés la dimensió social de la problemàtica de la dona.

A finals del segle xix i a principis del xx la gran batalla era encara pel dret de les dones $i$ les nenes a l'educació, pel seu dret a accedir a tots els nivells d'instrucció ${ }^{3}$ i a totes les professions, encara que en aquest terreny fins $\mathrm{i}$ tot les feministes es limitaven a demanar l'accés a les pro-

3. Scanlon, op. cit., 1976, p. 56. Fins el 1910 era necessari que les dones sollicitessin un permís especial a les autoritats acadèmiques per a matricular-se a la Universitat. 
fessions liberals, educatives i burocràtiques. El 1900 el percentatge de dones analfabetes era d'un $54 \%$ i d'un $36,8 \%$ el d'homes.

Els sectors més dretans, més conservadors i més religiosos consideraven el dret a l'educació de les nenes, en les mateixes condicions que els nens, com un atemptat a la natura femenina, i la coeducació com a font de tots els vicis $\mathrm{i}$ totes les immoralitats.

Així $i$ tot l'escola mixta va ser un fet en les experiències aillades ja citades i sobretot en les escoles unitàries rurals on un nombre reduit d'alumnes no permetia tenir dos mestres, un per a nens $i$ un per a nenes, ni tampoc un mestre per a cada grau. De totes maneres la llei d'Instrucció Pública del 1857 recomanava que els nens i les nenes estiguessin ben separats en les escoles unitàries. Les prevencions sexistes es difuminaven molt quan es tractava de l'escola dels pobres.

\section{La coeducació a la República}

A les Corts Constituents de la Segona República el tema de la coeducació hi era present. En el projecte de llei encarregat al Consell d'Instrucció Pública es considerava essencial «l'establiment de la coeducació en tots els graus de l'ensenyament».

Tanmateix, el debat essencial en aquells moments es concretava en l'escola única, la gratuitat i la laicitat. Per part dels sectors republicans i socialistes es propugnava l'escola igualitària, però aquest adjectiu s'entenia molt més pel que $\mathrm{fa}$ a les classes socials que pel que $\mathrm{fa}$ als sexes. Així, malgrat que la Constitució assenyalés en el seu article 29 que «No podrán ser fundamento de privilegio jurídico la naturaleza, la filiación, el sexo, la clase social, etc...», l'article 48 , dedicat a l'ensenyament, no mencionava per res el tema de la coeducació. Ni l'Estatut del 1932, ni l'Estatut interior del 1933 no diuen tampoc res sobre el tema. Com a experiència d'avantguarda, el 26 d'octubre de 1931 es creava l'Institut Escola que admetia alumnes d'ambdós sexes. La reforma de les Escoles Normals realitzades per Marcellí Domingo el 1931 establia que el professorat i l'alumnat fossin mixtos. En les escoles primàries s'acordà el reconeixement oficial de l'experiència coeducativa per a determinats centres, alguns ja existents, $o$ d'altres entre els que es crearen de bell nou en el període republicà.

En el curs 1933-1934 el nombre d'escoles mixtes graduades del total d'escoles estatals era d'un $29 \%$, mentre que les escoles unitàries constituien un $63,9 \%$ del total. ${ }^{4}$ Així doncs, si bé podem dir que la majoria

4. Mariano Pérez Galán, La enseñanza en la II República, dins «Cuadernos para el Diálogo», EDICUSA, Madrid, 1975, p. 341. 
de nens i nenes anaven junts a l'escola, el pes aclaparador de les escoles unitàries amb el seu baix nivell pedagògic - s'hi barrejaven alumnes d'edats $\mathrm{i}$ coneixements diversos - fa que aquesta experiència d'escola mixta no fos en molts casos tan positiva com hauria calgut.

\section{Opinions sobre la coeducació}

A causa de l'estructura educativa del país l'escola mixta era a la pràctica un fet, però un fet en general mal assumit en el seu aspecte pedagògic $\mathrm{i}$ teòric.

Els sectors catòlics més retrògrads continuaven atacant la coeducació, primer de paraula i més tard, el 2934, de fet. S'inspiraven en la concepció de la dona que oferia l'Església i en l'encíclica de Pius XI Divinis Illius Magistri del 1929. En aquesta encíclica es considerava la coeducació com a errònia i perniciosa per a l'educació cristiana, se l'acusava de basar-se «en el naturalisme negador del pecat original i a més, segons tots els sostenidors d'aquest mètode, en una deplorable confusió d'idees que bescanvia la legítima convivència humana en una promiscuiltat $i$ una igualtat nivelladores». Més endavant s'afirmava: «No hi ha en la mateixa naturalesa que els $f a$ diversos en l'organisme, en les inclinacions $i$ en les aptituds cap motiu perque hi pugui o degui haver promiscuitat i molt menys igualtat de formació per a ambdós sexes.» La fatalitat del pecat original i el naturalisme cristià que legitima la inferioritat específica de la dona són les idees centrals d'aquesta condemna que ja és prou clara per si mateixa perquè calgui comentar-la més.

Altres opinions més favorables sorgien de les organitzacions dedicades a l'ensenyament, però eren sovint declaracions generals de principis que no aprofundien en els aspectes pedagògics $\mathrm{i}$ ideològics que comportava l'escola mixta. Així la Federació Espanyola de Treballadors de l'Ensenyament considerava: "Los niños vant a ir juntos a la escuela, que es el bogar de educación, $y$ van a convivir allí, bermanos y hermanas como en el propio bogar. Juntos aprenderán las normas rectas y justas del vivir $y$ se solidarizarán para el trabajo y el amor.» ${ }^{5}$ L'escola era la continuïtat de la família, i no es qüestionava ni l'una ni l'altra.

La coeducació va ser objecte d'una mínima reflexió a les Escoles d'Estiu dels mestres de Catalunya. En les conclusions de la del 1933 es deia: «Cal que els infants d'ambdós sexes es tractin a l'escola amb la major naturalitat. No s'ha d'exercir sobre d'ells cap pressió per tal de que alter-

5. Pérez Galán, op cit., 1975, p. 224. 
nin o estiguin separats...»: podem veure com des de posicions encontrades com són la de Pius XI i la de l'Escola d'Estiu la naturalitat (quina?) es considera un element essencial. Per a uns i altres aquest tema té accepcions diferents però la natura comparteix una autoritat legitimadora quan es parla dels sexes. Per els mestres de Catalunya, com per a tots els partidaris de la renovació pedagògica en la República, l'escola havia de ser igual per tots els infants $\mathrm{i}$ si en les conclusions citades es mencionava explícitament que calia superar a l'escola les diferències d'origen econòmic i social s'oblidava «naturalment» la situació discriminada o desigual de la nena i de la dona a l'escola i a la societat. L'escola, creien, reunia nens $i$ nenes i deixava que es relacionessin de forma lliure i natural, prescindia de tots els condicionants socials $i$ ideològics, $i$ feia que uns $i$ altres esdevinguessin iguals.

La conclusió 15 de la mateixa escola d'estiu també tractava el tema: «Totes les informacions sobre diverses qüestions sexuals, ocasionals o sistemàtiques segons l'edat dels nens, són sempre indicades a l'Escola mentre es facin amb discrecio, esperit científic $i$ naturalitat. Contribueix a ennoblir la sexualitat $\mathrm{i}$ a donar-li un caràcter especulatiu, que tan necessari és per a controlar els poderosos moviments afectius que provoca.» (El subrallat és meu.)

Per fi es reconeix l'existència de la sexualitat a l'escola! Però malauradament la constatació d'aquesta realitat té per objecte allunyar la possibilitat d'assolir el plaer i d'ésser viscuda pels mateixos infants. Se la converteix en una matèria teòrica $i$ abstracta capaç de reprimir la sexualitat infantil.

La declaració de l'Escola d'Estiu continuava: «La major part de les activitats escolars poden acomplir-les junts; algunes, les més pròpies de cada sexe, separadament. La coeducació a l'escola no s'ha de proposar mai reduir o llimar les característiques diferencials biològiques d'ambdós sexes. Pot, al contrari, fomentar-les dintre d'un to general profundament humà.» L'escola, se'ns diu, ha de ser conjunta menys en allo que correspon a cada sexe. I com que no es defineix què és, podem suposar que es tracta de les funcions $\mathrm{i}$ les atribucions tradicionals per a l'home i la dona: el treball $\mathrm{i}$ la llar, respectivament. La coeducació no ha de formar éssers neutres i indiferenciats, d'acord, però quins són els límits de les diferències? Qui els assenyala? On s'acaba la biologia i on comença la cultura? Quins són els valors socials atribuits a unes $\mathbf{i}$ altres característiques biològiques? Respondre a tants d'interrogants podria donar lloc a un altre article, però només vull assenyalar aquí que determinats trets biològics sexuals comporten la imposició social $i$ cultural d'un seguit d'actituds i comportaments distints $\mathrm{i}$ valorats de manera diferent, als quals erròniament s'atribueix 
una causa natural i biològica. A la natura biològica s'afegeix una segona «natura» cultural i d'això pretén fer-se el conjunt de característiques biològiques. La biologia ho justifica tot. El text citat proposa aquesta trampa quan diu que a l'escola no s'han de «reduir les característiques diferencials biològiques». Ens sembla difícil que una escola pugui abordar una tasca que entra de ple en el camp de la medicina més especialitzada.

La coeducació que ens proposa l'Escola d'Estiu decideix educar conjuntament nens i nenes malgrat reconèixer l'existència d'una certa especificitat, però l'especificitat que proposa per a les nenes és subordinada, és la mateixa que es troba a totes les esferes de la societat, i aquesta diferenciació es fa de forma molt subtil perquè es refugia en la igualtat falsa $i$ formal que presideix tota l'obra reformadora de l'època.

$\mathrm{El}$ tractament d'aquestes diferències queda recollit en el punt 30 del règim intern de l'Institut Escola: «L'ensenyament domèstic que, en general, es dedicarà a les noies (en lloc de certs treballs manuals i els d'obrador dels nois) les orientarà envers la resolució conscient dels problemes promoguts pels afers domèstics, $i$ les illustrarà respecte als treballs casolans, a la constitució de la família, a la cura dels infants, als serveis d'infermeria, i desvetllarà en elles ensems l'amor als nens desvalguts.» Com podem veure, l'educació tradicionalment femenina per a la llar i per a l'amor quedava assegurada en un dels centres escolars que es poden considerar més avançats, en el terreny pedagògic, a l'època de la Generalitat i la República.

En la creació del Consell de l'Escola Nova Unificada, l'any 1936, que es definia com l'escola per a tots els infants de la nació, es podia esperar una declaració explícita sobre l'escola mixta. No la trobem ni en la definició del CENU ni en la declaració de principis. L'onada igualitària que envaeix l'orientació pedagògica del moment deu considerar innecessari insistir sobre un tema que la pretesa igualtat escolar ja ha resolt. L'escola del CENU va ser mixta $\mathrm{i}$ aquest és un fet prou conegut, però l'única referència clara que en trobem al Pla general d'Ensenyament del CENU és entre parèntesi $i$ tot parlant de la distribució de les aules de treball. Aquesta pot ser una indicació de la importància que el tema havia arribat a assolir.

No voldria, però, que les crítiques i la necessària valoració fetes en les pàgines precedents des d'una òptica actual, quan l'escola mixta mal que bé porta alguns anys d'existència, ens fessin oblidar l'avenç extraordinari que per a les nenes de la Generalitat i de la República van significar la política educativa i les línies pedagògiques de l'època. L'escolarització conjunta, potenciada en el marc de l'escola activa, va suposar un gran pas endavant respecte a l'educació que havien rebut les nenes fins 
aleshores. Una educació menystinguda i amb menors exigències de nivell, abandonada sovint a mans de monges i amb una especial dedicació en la costura $i$ en totes les matèries domèstiques i d'ornamentació. A més, l'impuls donat a l'escolarització en el període republicà va afavorir més les nenes que els nens:

\section{Percentatge de dones analfabetes a Espanya ${ }^{6}$}

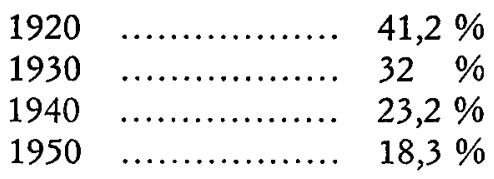

Podem veure que l'any 1930 el percentatge ha minvat en un $22 \%$ respecte al 1920, l'any 1940 en un $28 \%$ respecte a l'anterior, i l'any 1950 un $21 \%$ respecte al 1940 . Així, doncs, es va produir un salt entre 1930 1940 dins de la tendència decreixent de la xifra de dones que no sabien llegir ni escriure. Són les noies que van anar per primera vegada a l'escola durant la República. És prou conegut el nul interès que el franquisme va dedicar a l'escolarització, les xifres ens mostren que l'any 1950 ha ralentit la disminució de l'analfabetisme.

Si analitzem les dades d'escolarització durant la República en l'ensenyança primària i secundària veiem com, dins de l'augment general, el creixement de les noies és superior: del curs escolar 1932-1933 al 19341935 les nenes que anaven a l'escola primària van augmentar en un $12 \%$ i els nens en un $9 \%$; pel que fa a l'ensenyament secundari, el creixement de les noies va ser molt més espectacular: un $262 \%$ sobre un $30 \%$ dels nois entre els cursos 1930-1931 i 1934-1935.7 Aquesta crescuda en l'escolarització femenina s'explica perquè dins del dèficit general —els nens i les nenes que anavén a l'escola primària eren només un 52,9\% del total de la població en edat escolar l'any 1935- les nenes eren les més perjudicades $i$ les que per tant van ser més beneficiades per la construcció de centres educatius que va emprendre la República.

Així, doncs, si bé és cert que l'escola mixta no vol dir d'entrada la superació de l'escola sexista, sí que certs debats educatius podien semblar -i amb això no vull dir que ho fossin- secundaris quan més d'un milió

6. Fundación Foessa, Estudios sociológicos sobre la situación social en España, Euramérica, Madrid, 1975, p. 212.

7. «Anuario Estadístico de España», Madrid, 1951, p. 757. 
de nenes, o sigui un $50 \%$ el 1934, no tenia escola, ni mixta ni separada, on anar.

Tan aviat com ho permeté la reacció dretana iniciada el 1933 s'atacà l'escola coeducativa. Per una ordre del 1934 es recordava que el Ministeri no havia fixat mai normes generals sobre aquest tema i que, per tant, "queda sin efecto el régimen de coeducación establecido y sin autorización ministerial, probibiéndose a los maestros e inspectores su implantación en las escuelas primarias nacionales, exceptuando las escuelas mixtas y de párvulos para las que está determinado por precepto de ley y por necesidades pedagógicas. ${ }^{8}$

La coeducació s'admetia com a experiment però no com a norma general. Val la pena ressaltar que aquestes mesures es produïen conjuntament a la devolució als ordes religiosos de les escoles incautades l'any 1931.

Els atacs no van acabar aquí. Francisca Bohigas, diputada de la CEDA que tornarem a trobar els anys quaranta com a teòrica en pedagogia de la Secció Femenina de la Falange, va presentar una proposta de llei intentant restablir les Escoles Normals d'un i altre sexe i per a fer retrocedir la reforma que havia emprès Marcellí Domingo. Els professors i els alumnes de les Normals van reaccionar contra aquest intent reaccionari que pel forat de la promiscuïtat i l'escàndol volia fer passar tota l'obra renovadora de les Escoles Normals. En aquells moments la coeducació existia ja a la Universitat, als instituts, a les escoles de comerç, al conservatori, a l'Escola Central d'Idiomes i a les escoles mixtes primàries. En la defensa de la nova experiència els professors de les normals adduien que «las muchachas ban agrandado su horizonte social y cultural y los muchacbos corrigen su lenguaje y modales»," i tenien molta cura a demostrar que no s'havia produit cap abús de tipus sexual pel fet que els nois i les noies seguessin de costat. Finalment, i després d'una forta polèmica, les Normals van continuar essent mixtes.

En el debat entorn de l'ensenyament en la Segona República es poden seguir bastant bé els temes de fons, socials i ideològics, que van recórrer aquell període. Pel que fa a la situació de les dones, també existeix un cert parallelisme. La dona va veure afavorida la seva condició bé per mesures legals, o bé, indirectament, per tot el que suposava millors condicions de vida i treball, l'accés que se li permetia a la vida pública, i la lenta influència que els canvis legals o el debat polític $i$ ideològic podien tenir en els costums.

Però la situació profunda de la dona en la societat i en la família

8. Pérez Galán, op. cit., 1975, p. 224.

9. Pérez Galán, op. cit., 1975, p. 230. 
no va canviar gaire. El que en definitiva varià positivament durant la $\mathrm{Re}$ pública fou el context social i polític en què es podien moure les dones: elles, com a tals, no van tenir temps d'encetar la lluita per a millorar la pròpia situació. No en van tenir temps, no van poder o no ho van veure necessari. El cas és que les mesures igualitàries (jurídiques o no), per molt formals i limitades que fossin, eren, i ho són encara avui, un considerable pas endavant. $\mathrm{La}$ desigualtat es pot comprendre $\mathrm{i}$ vèncer millor quan tot proclama la igualtat.

\section{El franquisme i la submissió de les nenes}

L'impacte ideològic, de costums, del franquisme ha estat contundent però quallà de forma més lenta que l'allau legislativa que, en pocs mesos, arrasà tota l'obra jurídica, social i educativa realitzada per la República i la Generalitat.

Els nous corrents educatius que havien florit en el periode anterior foren atacats per sla falta de instrucción fundamental y de formación doctrinal y moral, el mimetismo extranjerizante, la rusofilia y el afeminamiento (...) todo ello en contradicción dolorosa con el viril beroísmo de la juventud en acción» (preàmbul de la llei de 20 de setembre de 1938).

L'exaltació dels valors més masculins inspirava el nou règim i l'atac a les conquestes assolides per les dones no es limitava al terreny legal. Tota una moral arrelada en el pensament catòlic més tradicional resorgia per ancorar la dona en les essències de la llar. El marc social i polític havia canviat $\mathrm{i}$ aquesta era també la gran derrota per a les dones.

La Secció Femenina de la Falange va ser l'encarregada de formar el nou tipus de dona que la Pàtria necessitava. Una sèrie de lleis va posar a les seves mans la formació política i casolana de les nenes $i$ de les dones:

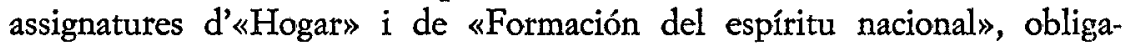
tòries a l'ensenyament, el servei social, també obligatori, etc. constituien l'estructura a partir de la qual s'havia d'educar i reeducar les dones. ${ }^{10}$

Per a difondre les seves idees sobre la «nueva mujer de España» la Secció Femenina va crear un material de propaganda: revistes, fulletons, etcètera. En el camp pedagògic destaca la revista «Consigna», creada l'any 1941, especialment dedicada a les mestres. Una de les teòriques en pedagogia de la revista era Francisca Bohigas de la qual ja hem parlat.

Del conjunt d'articles fets per ella dedicats a l'ensenyança i a les pro-

10. Elena Posa, Una educación particularmente femenina, dins «Cuadernos de Pedagogía», núm. 31-32, juliol 1977. 
fessions de la dona se'n poden extreure els perfils generals que el franquisme i la Secció Femenina volien donar a aquest tema.

Però abans cal recordar que el 1938 s'havia prohibit la coeducació, sistema «contrario enteramente a los principios religiosos del Glorioso Movimiento Nacional y, por tanto, de imprescindible supresión por antipedagógico $y$ antieducativo para que la educación de los niños y las niñas responda a los principios de sana moral y esté de acuerdo con todos los postulados de nuestra gloriosa tradición».

En aquesta prohibició no hi ha solament un plantejament antifemení, sinó tota l'alenada de la moral judeo-cristiana que reclama la separació total dels sexes, la diversitat de funcions en la vida i el record del pecat original que trobàvem en l'encíclica Divini Illius Magistri.

Reclamar «los postulados de nuestra gloriosa tradición», a part de reivindicar un imperi i la dominació de molts pobles, vol dir reclamar les diferències, $i$ per tant la inferioritat, de la dona.

La revista "Consigna» ho expressava aixi: «Conviene no perder el tiempo, ya de suyo breve, de que disponemos para la formación de la mujer...» Les nenes no podien dedicar el mateix temps a l'educació que els nens perquè havien d'ajudar a casa, per això «la instrucción que reciban se referirá a cuestiones fundamentales $y$, especialmente con aplicación al hogar, al cuidado de la familic y de los niños». L'ensenyament per a la dona havia de ser, doncs, qualitativament i quantitativament inferior. La desigualtat formal i real s'havia imposat: «No podrán emplearse los mismos cuestionarios que se utilicen para la insirucción de niños de edad y condiciones análogas de desarrollo, porque las niñas ban de cumplir su fin bistórico con otro género de trabajos.»

Però encara que fos diferent, l'educació de la dona, en allò que li era propi, no podia ser superficial «pues sería absurdo pretender bijos bien educados moralmente $y$ capaces de virtudes beroicas, si previamente no educamos a las madres para que puedan ser ejemplo y estimulo permanente para sus bijos»." Així, doncs, per al franquisme era antipedagògic $i$ antieducatiu que l'home $i$ la dona tinguessin el mateix dret a l'ensenyament perquè com a éssers humans no tenien els mateixos drets ni les mateixes funcions. El destinatari de l'obra i de l'educació de la dona no era ella mateixa sinó els seus fills.

Un cop suprimida la coeducació, el franquisme ja no en parla més, però val la pena veure quin ha estat l'enfocament de l'educació femenina

11. Aquesta cita i les precedents són de F. Bohigas, Orientación pedagógica, dins «Consigna», núm. 29, 1942. 
per a fer-ne el contrapunt amb els plantejaments coeducatius anteriors o actuals.

Els objectius de l'educació de la dona eren evidentment aquells que l'havien d'ajudar a ser més dona: «Abarcar los fines y obligaciones que la mujer babrá de cumplir durante su vida: crear bijos, educarlos, administrar un bogar y crear valores morales.» «Si no tiene recursos económicos, además tiene que ejercer una profesión, pero jamás deberá renunciar al cumplimiento de aquellas funciones que le son propias.» ${ }^{12}$

La professió era vista com a quelcom de secundari per a les dones, un remei per a les dones pobres, l'últim recurs quan el matrimoni no s'havia produït o quan el sou del marit no permetia viure. En un o altre cas el treball es plantejava com una desgràcia que mai no podia fer oblidar les obligacions prioritàries. I és que les funcions de la dona són vistes com a deures que es deriven de la seva condició (natural) de femella. La naturalesa justifica aquesta funcionalitat. Trobem un altre exemple de com una segona «natura» de tipus cultural es crea a partir de la primera. I a partir d'aquí es pot establir l'autoritat dels deures i les obligacions: qui mana, segons aquest raonament, no és sinó la natura.

El rol maternal està relacionat amb l'educatiu: «La madre es la gran educadora dentro de la familia.» Però no ho és en el sentit de saber, de teoria, de cultura, això queda reservat als homes en els nivells superiors de la instrucció. A la família «se adquieren condiciones y bábitos». La dona educa per la pràctica, per la repetició, se la considera incapaç de transmetre cap coneixement de forma teoritzada. La mare ha de posseir aquells elements que «de una manera espontánea, pero eficaz, babrá de transmitir a sus bijos» (el subratllat és meu). Així ens trobem que cal educar la dona perquè sigui dona, $\mathrm{i}$ aquesta educació de la feminitat ha d'arrelar tan profundament perquè sigui dona de manera natural i espontània.

La dona educa, doncs, perquè s'ha fet dona, no cal que posseixi coneixements molt elevats, sinó valors morals i hàbits, perquè és això el que ha de transmetre als fills per a mantenir la coherència de la família i de la societat. La raó, el pensament, el coneixement queden allunyats, reservats al món dels homes. A ella li correspon el món de la pràctica, dels costums quotidians, dels afectes.

Respecte a aquesta educació moral aconsellava la revista «Consigna»: «Por poco tiempo que asista a la escuela, por breve que sea un cursillo de perfeccionamiento a que se la invite o someta, deberá recibir ideas claras y breves acerca de la existencia de Dios $y$ de su divina Providencia

12. F. Bohigas, op. cit., 1942. 
$y$ acerca del origen $y$ fin del bombre para conocer su dependencia y conocimiento del orden moral.»

L'extraordinària importància que per a Francisca Bohigas i Pilar Primo tenia la formació religiosa i moral era deguda a dos factors: d'una banda, sotmetre la dona a un rol tan rígid $i$ tan pretesament natural requeria una elevada dosi de repressió ideològica, que la dona havia d'assumir a partir de la inculcació d'una moral disciplinada que justifiqués el sacrifici; de l'altra, el lligam de la dona amb la societat es realitzava a partir del natural: la casa, els fills, tot allò que permet reproduir la vida quotidiana, $i$ on la dona havia de ser la reserva espiritual de virtuts. Calia que ho fos ella perquè l'home $i$ els fills trobessin a la llar l'obediència, l'amor, la comprensió, l'ajut, la resignació i el sacrifici. Virtuts que en la pràctica social no es valoren perquè no serveixen per a fer ni produir res. La nena se l'educa perquè sigui dona i prou. En l'home les virtuts són secundàries, és més important que sàpiga fer, i les seves transgressions morals són justificades com a compensacions del seu rol productor. Són les concessions que es permeten als qui fan el món. Els homes se'ls educa en els instruments directament funcionals per la imatge professional i social que han d'adoptar.

Les funcions «naturals» de la dona tenien a més una justificació sobrenatural per a la Secció Femenina. Les encícliques havien de ser la font orientadora de l'educació, perquè «en estas Encíclicas se define cómo debe entenderse y practicarse la vida de familia para que la familia pueda cumplir sus fines, impuestos por Dios, creador y conservador de cuanto existe...» Respecte a l'educació femenina es deia: «Si queremos educar, formar madres cristianas, tenemos que buscar en las Encíclicas las obligaciones, las virtudes necesarias para cumplirlas y los apoyos que se requieren para que la mujer pueda cumplir su misión de mujer cristiana y estas enseñanzas, dadas de manera clara y completa, constituirán el $A B C$ de la formación femenina.» Si la biologia no era argument suficient hom podia recórrer a la fe.

\section{Unes conclusions que no bo són}

Hem vist com les posicions a favor o en contra de l'escola mixta, al nostre país, han anat estretament lligades a actituds polítiques $i$ ideològiques més progressives o més reaccionàries.

¿Vol dir això que el projecte polític de la burgesia progressista i de les classes populars ha anat sempre vinculat a una alternativa feminista d'emancipació? No exactament, però sí que els únics projectes polítics que 
han defensat, encara que de forma limitada i discutible, la promoció i la igualtat de la dona -en general no han passat d'aquí- han estat ideats o duts a terme per la classe obrera $i$ alguns sectors de la burgesia democràtica.

Però una vegada constatada la vinculació del grau de llibertat de les dones a unes o altres formes polítiques - $i$ subratllo el mot grau-: què han representat l'escola mixta i l'escola separada per al trasbalsament de les funcions patriarcals perpetuades en una escola sexista?

Els apologistes de l'escola separada ho han estat per dues raons bàsiques: l'una creure que l'educació de les nenes havia d'anar prioritàriament dedicada a fer-ne dones que poguessin servir a la família, per tant, aquesta educació diferenciada, encara que es justifiqués com a essencial per als fills, el marit i la llar, era culturalment inferior; l'altra, d'ordre moral, es basava en la convicció que el contacte dels sexes i per tant dels infants era font de pecat perquè mentre es negava la sexualitat pròpia de la dona se la feia inductora de tots els vicis masculins.

L'escola femenina que han teoritzat el franquisme i l'Església ha exaltat la maternitat, la incultura i l'acientifisme, la dependència de l'home, la por a la intelligència i als sentits, i el convenciment de la pròpia inferioritat. I ho ha fet en veu alta, assumint un discurs sexista $i$ duent-lo a terme abandonant en mans de les monges o de la Secció Femenina la formació de les futures mares del país.

L'escola coeducativa ha tingut una existència molt precària i ha estat menys teoritzada que l'altra. El terme coeducació no falta en els projectes polítics de les forces democràtiques del país al llarg del segle, però tot s'acaba en l'enunciat. I com que en general no s'explica, deduïm que per coeducació s'entén paritat.

A finals de segle s'argumentava que la dona sortiria de la seva inferioritat educant-se amb l'home i com l'home. Aquest raonament és el que encara subsisteix avui a l'escola mixta o coeducativa.

Amb la República es considera que homes i dones ja són iguals, i, per tant, es fa el discurs de l'ésser humà, es pretén oblidar l'existència dels sexes a l'escola - tots són infants- i la primera manera de fer-ho és no parlant-ne. Teòricament tots són iguals, però no en els fets ni en la pràctica escolar - comporti o no matèries diferenciades.

En el fons, l'argumentació sobre l'escola mixta no ha variat des dels seus orígens. Ha tractat d'integrar les nenes en el que havia estat $\mathrm{i}$ és la cultura masculina, deixant de costat, a l'hora de configurar els continguts i els valors generals d'aquesta escola, tot allò que forma el món de les dones. Però al mateix temps no ha deixat mai de recordar a les nenes que per a elles existien unes funcions $i$ uns comportaments especifics. 
Aquesta continuïtat en l'orientació de l'escola mixta la podem constatar en un informe de la UNESCO de l'any $1970^{13}$ on s'afirma que l'escola mixta prepara millor per a la vida, ja que la sana emulació de nois i noies afavoreix la camaraderia, procura a les noies una major obertura d'esperit, les estimula en la competició i els dóna un nivell més elevat d'estudis. En definitiva, l'escola mixta situa els infants en les condicions naturals de la família, de la vida social, de la professió, i eleva els coneixements de les noies.

A l'hora de fer el balanç sobre el caràcter discriminador de l'escola mixta podem preguntar-nos com Liliane: «Res no diu, per exemple, que la coexistència precoç i prolongada entre grups (és a dir, la preparació per a "treballs pràctics", $\mathrm{i}$ no solament per classes teòriques, com en el cas de la no mixtitat) tingui efectes exclusivament "reproductors" de l'ordre patriarcal. Res no permet de dir exactament si, $i$ en quines condicions, l'escola mixta pot assegurar una domadura millor $i$ un aprenentatge mutu encara més eficaç dels rols sexuals de subordinació i de dominació, o si, al contrari, els esborra progressivament.» ${ }^{14}$

Repassats els problemes essencials de l'escola separada i de l'escola mixta tal com s'han entès funs ara, podem preguntar-nos per on ha d'anar el plantejament d'una escola no sexista.

Una escola on es potenciin les aportacions i els comportaments femenins, on les nenes no sentin la discriminació quotidiana respecte als seus companys, on adquireixin la seguretat de ser nenes $i$ futures dones, ha de ser una escola separada?

Aquesta tendència, que podria semblar la més feminista, em semblaria desencertada, perquè, a nivell general, l'escola separada no faria sinó reproduir el model femení familiar, perquè ni les nenes, ni les mestres, ni les dones podem avui donar aquesta alternativa feminista a l'escola a escala global del país. Separar-se per a construir un nou model de nena/dona fóra una experiència d'avantguarda, i si el que volem no és tan sols canviar les nenes/dones, sinó el seu paper en la societat -que són processos inseparables-, i per tant que aquesta es transformi, cal projectar d'entrada el canvi en l'educació de les nenes dins del canvi de tot l'ensenyament: és a dir, l'educació d'ambdós sexes.

Aquesta proposta de no mixtitat a la pràctica suposaria tornar al gbetto, i per molt feminista que aquest fos, socialment comportaria encara la inferioritat i la discriminació. Com hem vist, històricament separar vol

13. UNESCO, Étude comparé sur l'enseignement mixte, 1970.

14. Liliane, «L'école des femmes et le discours des sciences de l'homme», dins Les femmes s'entêten, Gallimard, París, 1975. 
dir marginar i subordinar, i la lluita de les dones no és solament per al nostre propi reconeixement com a sexe, sinó també perqué la nostra autonomia comporti l'acceptació social d'un nou model de dona i, lògicament, també d'home.

I dic això creient que el moviment ha de ser autònom, la seva lluita específica, $i$ que les feministes hem de dur a terme la nostra pròpia reflexí́ a l'entorn de l'escola, la coeducació i l'ensenyament. Són les condicions necessàries perquè les nostres reivindicacions no quedin confoses $i$ oblidades dins tots els projectes de transformació social i educativa.

El debat sobre una escola no sexista s'ha de plantejar a partir de la pròpia coeducació, qüestionant la seva falsa esperança igualitària, però aprofitant-ne precisament tot el que avui té de contradictori. Apuntant cap a una escola que reconegui amb igualtat de condicions el paper de les nenes $\mathrm{i}$ les dones $\mathrm{i}$ totes les aportacions que aquestes poden fer, que integri ambdós sexes i n'equipari els valors $i$ les conductes, sense que això vulgui dir uniformitat, repressió o minva de la lliure personalitat de cada individu.

Aquest debat es pot iniciar avui $i$ anirà forçosament vinculat a les propostes feministes sobre un nou paper de la dona en la societat i sobre la transformació dels rols tan masculins com femenins.

Però perquè el debat es transformi en realitat cal que s'accepti d'entrada que a l'escola, com a la societat i a la família, existeix la subordinació de la dona, i que en descobreixin junts -mestres i alumnes- els mecanismes. La primera condició per a l'alliberament és acceptar l'existència de l'opressió; la segona, saber què entenem per alliberament. Totes les dones i especialment les mestres $i$ les nenes tenim la paraula. 